\title{
Shades of Belonging: The Intersection of Race and Religion in Utah Immigrants' Social Integration
}

\author{
Jane Lilly Lopez *, Genevra Munoa, Catalina Valdez and Nadia Terron Ayala
}

check for updates

Citation: Lopez, Jane Lilly, Genevra Munoa, Catalina Valdez, and Nadia Terron Ayala. 2021. Shades of Belonging: The Intersection of Race and Religion in Utah Immigrants' Social Integration. Social Sciences 10: 246. https://doi.org/ 10.3390/socsci10070246

Academic Editors: Pawan H. Dhingra and Tanya Golash-Boza

Received: 26 March 2021

Accepted: 22 June 2021

Published: 26 June 2021

Publisher's Note: MDPI stays neutral with regard to jurisdictional claims in published maps and institutional affiliations.

Copyright: (c) 2021 by the authors. Licensee MDPI, Basel, Switzerland. This article is an open access article distributed under the terms and conditions of the Creative Commons Attribution (CC BY) license (https:/ / creativecommons.org/licenses/by/ $4.0 /)$.
Department of Sociology, 2008 JFSB, Brigham Young University, Provo, UT 84602, USA; genevra.k.munoa@vanderbilt.edu (G.M.); catalinavaldez@byu.edu (C.V.); nterron@byu.edu (N.T.A.)

* Correspondence: jane_lopez@byu.edu

\begin{abstract}
Utah, USA, a state with a unique history of immigration and a distinctive religious context, provides a useful setting in which to study the intersection of racism and religious participation with immigrant integration. Utah is one of the Whitest states in the United States, with 4 of every 5 residents identifying as non-Hispanic White. It is also home to the headquarters of the Church of Jesus Christ of Latter-day Saints (LDS Church) which, until 1978, explicitly imposed race-based exclusions that prohibited or strictly limited Black members' participation in church leadership, rituals, and ordinances. The state's cultural, social, and religious history has contributed to widespread beliefs among modern Utah residents of Whites' racial supremacy in contexts both mundane and divine. Much of Utah's population growth since 1960, especially among non-White racial and ethnic groups, can be attributed to immigrants, who today compose nearly 10 percent of the state's population. Given Utah's religious, social, and cultural relationship to race, it is an ideal case to study the following question: how do race, religion, and culture shape integration among immigrants? Utilizing interviews with 70 immigrants who have lived in Utah for an average of 13 years, we find that both race and LDS Church membership influence immigrants' social integration, creating a hierarchy of belonging among immigrants in Utah-with White LDS immigrants reporting the highest levels of integration and non-White, non-LDS immigrants reporting the lowest levels of integration. These findings suggest the power of cultural narratives-beyond explicit institutional policy and practice--in perpetuating racial inequality in society. Thus, efforts to increase integration and belonging among immigrants must not only include work to dismantle legal and structural inequalities but also efforts to actively change the cultural narratives associated with them.
\end{abstract}

Keywords: immigration; integration; colorism; religion; belonging; racism; racial inequality

\section{Introduction}

Institutional policies, practices, and cultures all affect immigrants' integration experience and sense of belonging in the host society. Governmental and non-governmental institutions can help facilitate immigrant integration by offering structural and social inclusion (Bloemraad 2006; Ebaugh and Curry 2000); they can also impede immigrant integration through explicit exclusions enacted with policy and implicit exclusions reinforced through institutional practices and cultural diffusion (Lee 2013; FitzGerald and Cook-Martin 2014). In the United States, race-based exclusions have historically been both explicitly and implicitly imposed through governmental policies and practices, non-governmental policies and practices, and widespread social and cultural norms and narratives designed to uphold white supremacy and normalize racial inequality (Kim 1999; Waters 1999; FitzGerald and Cook-Martin 2014; Flores-González 2017). These race-based exclusions have directly and indirectly affected immigrants' experiences with integration and perceptions of belonging in the US (Zhou 1997; Kim 1999; Jiménez 2010; Jiménez and Horowitz 2013).

Explicit race-based exclusions in the US have largely disappeared from governmental and non-governmental policies over the past half-century following the passage of Civil 
Rights legislation beginning in the 1960s. However, implicit racial exclusion through cultural and institutional practices and norms continues to shape the opportunities and experiences available to all members of society—including immigrants-based on race (Bonilla-Silva 2001). Until 1965, the United States imposed explicit race-based restrictions in its immigration laws (Chin 1996), and until 1978, the Church of Jesus Christ of Latter-day Saints (LDS Church) strictly limited Black members' participation in church leadership and rituals (Reeve 2016). Although both the US government and the LDS Church have abandoned and denounced these race-based exclusions (see LDS Church n.d.b), the cultural narratives and norms developed to sustain former policies of inequality have proven harder to root out (Armenta 2017; Livingston 2018; Romanello 2020).

Utah, USA, a state with a unique history of immigration and a distinctive religious context, provides a useful setting in which to study the intersection of racism and religious participation with immigrant integration. In this study, we seek to understand how race and religious affiliation shape belonging among immigrants in Utah, home to the LDS Church headquarters and a growing, diverse immigrant population. We find that both race and LDS Church membership influence interviewees' social integration, with White LDS immigrant interviewees experiencing the highest levels of integration and non-White, non-LDS immigrant interviewees experiencing the lowest levels of integration. These findings suggest the power of cultural narratives-beyond explicit institutional policy and practice - in perpetuating White supremacy and racial inequality in society.

\section{Race, Religion, and Immigrant Integration in the United States}

Between 1790, when the United States Congress passed the country's first official immigration policy to limit citizenship to "free White" men, and 1965, when the last explicit racial exclusions were eliminated from US immigration law, white supremacist preferences featured heavily in most US immigration laws (FitzGerald and Cook-Martin 2014). White supremacism in US immigration law manifested in preferences for immigrants whose ethno-national backgrounds were racialized as White ${ }^{1}$ and explicit exclusions for immigrants whose ethno-national origins were definitively not White (López 1997; Lee 2013; Molina 2014; FitzGerald and Cook-Martin 2014). These explicit race-based policies of in/exclusion contributed both to the maintenance of the US population as being majority White and a specific understanding of Americanness as "Whiteness", limiting cultural understandings of who can truly "belong" in the US (Kim 1999; Lee 2013). In the half-century since these explicit policies ended, concerns around immigrant "illegality" and the criminalization of immigrants have increased precisely when a majority of immigrants settling in the US (both those with legal status and those without) come from ethno-national backgrounds considered to be non-White (Bonilla-Silva 2001; Armenta 2017). Cultural narratives surrounding immigrant "worthiness" and belonging that traffic heavily in race-based assumptions and prejudice continue to shape immigration policies and social rhetoric today, long after explicitly race-based immigration policies have been abandoned (Bonilla-Silva 2001; Golash-Boza 2015; Armenta 2017).

These cultural narratives around immigration and race, coupled with broader notions about race in the US, directly shape immigrants' integration experiences in the US. Despite the fact that race is socially constructed and racial categories are fluid within and across social contexts, race continues to play an outsized role in shaping the opportunities and experiences of all individuals living in the US, including immigrants (Hodes 2003). Scholars have documented how non-White immigrants, including those from the most privileged socioeconomic backgrounds in their home countries, confront significant structural and cultural barriers to integration due to racism and racial inequality that result in "downward" or "segmented" integration and incomplete belonging (Waters 1999; Zhou 1997; Kim 1999; Flores-González 2017). These scholars have emphasized that the race-based barriers to and opportunities for integration differ based on race, skin color, and country of origin, often working in concert to set different groups in opposition to each other in order to maintain White racial supremacy (Kim 1999). 
Building on these findings, recent scholarship has focused on "new" immigrant destinations to examine how the dynamics between legal, racial, cultural, and political narratives tend to play out in rural and suburban communities that have only recently begun to experience large influxes in their immigrant populations. In these contexts, scholars have identified racial triangulation in both occupational and social settings designed to maintain the racial hierarchy with Whites at the top and Blacks at the bottom (Kim 1999; Maldonado 2006; Marrow 2011; Ribas 2016; Silver 2015). At times, racial triangulation creates openings for newly arrived Latinx immigrants whose less-fraught racial history with Whites leads to their increased access to social, educational, and other opportunities (Silver 2015), but at other times, it reinforces the notion of immigrants (and, by extension, all Latinxs) as eternally other (Silver 2018). This triangulation also manifests in the positioning of all Latinxs (immigrants or not; with legal status or not) as "illegal", non-citizens, or otherwise legal and social outsiders in official legal and informal social contexts (Silver 2018; Dreby 2015). Skin color, language, and accent all play a role in the racialized criminalization of new residents in these communities (Dreby 2015; Golash-Boza and Hondagneu-Sotelo 2013).

These racial dynamics also interact with legal, political, and cultural forces to create a complicated landscape for migrant integration. In new immigrant destinations, in particular, migrants experience "tectonic incorporation" as political and social responses to in-migration fluctuate unpredictably, shifting opportunities for incorporation and complicating migrants' access to belonging (Silver 2018). Geography plays a role both practically and philosophically in these contexts, as access to services and civic participation is often constrained for non-English speaking immigrants and local cultural idiosyncrasies can present additional barriers to integration (Schmalzbauer 2014; Stinner and Toney 1980; Marrow 2011). While this research has produced a number of enlightening findings regarding immigrant integration experiences, it has almost exclusively focused on the experiences of Latinx migrants to new immigrant destinations. We seek to contribute to this line of scholarship by examining how race and racism shape integration for immigrants from a range of racial and ethnic backgrounds who settle in new immigrant destinations the US.

The burgeoning scholarship on the role of religion in shaping immigrant integration suggests that, overall, religious participation in the host country is largely a positive factor in migrants' experiences. Being part of a religious group can help with the transition between cultures as immigrants adapt to host countries, providing them with a strong identity tied to their religious affiliation (Kurien 1998; Cadge and Ecklund 2007). In the US, religious groups have been shown to provide forms of social and cultural capital not available in other settings (Ebaugh and Curry 2000; Foner and Alba 2008). However, the social and temporal benefits that religious affiliation provides migrants may only exist in some contexts (Bacchus 2020). Racism experienced within religious settings and racial difference from the congregational majority can complicate the integrative benefits of religious participation (Martinez and Dougherty 2013; Wright et al. 2015). In the LDS Church - where its history of race-based exclusion, embrace of White American culture, and international proselytizing have contributed toward fraught racial relations within its multi-racial membership - religious participation can bring both a sense of belonging and a sense of otherness for believers of color (Reiss 2019; Romanello 2020). Furthermore, in a setting in which one religion significantly predominates over others (as the LDS faith does in Utah), the potential (dis)integrative effects of religious affiliation for immigrants could be exacerbated by (non)participation in the majority religion of the region.

\section{Race, Religion, Immigration, and Culture in Utah}

While Utah has been historically and continues to be one of the Whitest states in the United States, it has experienced significant growth in its non-White population over the past half-century. Between 1960 and 2010, the non-White share of Utah's population grew from two percent to twenty percent (GPI 2017b). Immigrants and refugees compose a significant portion of Utah's growing non-White population. Today, one of every eleven Utah residents is an immigrant, and another one of every eleven Utah residents is a US-born 
citizen with at least one immigrant parent (AIC 2020). Utah is also home to more than 60,000 refugees composing at least two percent of the state's total population (GPI 2017a). Utah's history as a territory and state, founded by early LDS Church leaders in the mid1800s, is deeply rooted in immigration and the "pioneer heritage" of early Mormons who migrated to Utah from other parts of the US, Canada, Europe, and elsewhere to escape persecution and establish "Zion" (Mulder 1954a, 1954b).

This history of migration in the LDS Church-including the forced migration of early LDS Church members to escape persecution and an extermination order-has directly informed the LDS Church's ongoing support for compassionate approaches to immigration that "strengthen families and keep them together" (LDS Church 2018; Hartley 1838; Coppins 2020). The church has also experienced significant growth in its Latinx membership within the US and throughout North and South America, which has also contributed to its stance on immigration issues that contribute to political tensions in regions throughout the Americas. In its most recent statements regarding the institution's stance on immigration, the LDS Church has "promote[d] broad, foundational principles that have worldwide application", including "follow[ing] Jesus Christ by loving our neighbors ... includ[ing] all of God's children, in all places, at all times" and "recogniz[ing that] ... families are meant to be together", while also acknowledging "every nation['s ... ] right to enforce its laws and secure its borders" (LDS Church n.d.a). It has discouraged enforcement-only immigration policies and supports approaches allowing unauthorized immigrants to adjust to a legal status (LDS Church 2011). In 2018, the church also released a statement explicitly denouncing the forced separation of families at the border (LDS Church 2018). In addition to these official statements on governmental policy approaches, the LDS Church utilizes a number of "immigrant-friendly" practices throughout the world, including allowing the baptism and full fellowship of migrants regardless of their immigration status and establishing language-specific congregations (e.g., Spanish-speaking or Mandarin-speaking) in communities with significant populations of immigrant church members (Romboy 2008).

Although Utah ranks among the most politically and socially conservative states in the US, it has also generally adopted state and local policies that are favorable toward and inclusive of immigrants and refugees (Petrezelka and Jacobs 2016). Similar to other conservative states, Utah has approved some immigration enforcement-focused policies, such as a law authorizing law enforcement to verify an individual's immigration status in some contexts (2011; Park 2015). However, rather than focusing solely on passing state and local-level immigration policies that punish and exclude immigrants, Utah has also passed a number of "immigrant-friendly" policies in addition to enforcement-focused policies. These immigrant-friendly policies include: in-state tuition for undocumented residents (2002); driver's license and ID programs for undocumented immigrants (2005); the Utah guest worker program (2011); and a law to protect noncitizens convicted of misdemeanors from automatic deportation (2019; Park 2015; Stevenson and Lowe 2019). Utah's deviation from the GOP's laser focus on deterrence and exclusion is often attributed to the state's territorial history as a refuge for migrants fleeing persecution and the influence of the LDS Church in state politics; this influence includes a statistical over-representation of LDS Church members (most of whom have been swayed by the church's self-described "compassionate" approach to immigration) in state and local government offices (Davidson 2021; Vock 2011). This empathetic orientation to issues of migration has also been adopted and championed by other key members of Utah's public, private, non-profit, and service community, as exemplified by the Utah Compact (first adopted in 2010, reaffirmed in 2019) and its signatories (Vock 2011). Although this nuanced approach to immigration at the state- and local-levels does not insulate immigrants from federal immigration enforcement actions, it has contributed to a less-hostile environment for immigrants, especially unauthorized immigrants, than they tend to find in other red states (Liasson 2011; Park 2015).

While Utah and the LDS Church have consistently supported compassionate approaches to immigrants and immigration, their history and relationship to race and racism are much more fraught. Although the early LDS Church (founded in 1830) ini- 
tially preached among and welcomed into its ranks believers of all races and ethnicitiesincluding free Blacks, Native Americans, native Hawaiians, and indigenous and mestizo Mexicans-it pivoted away from this practice of racial and ethnic inclusivity by the 1850s, shortly after believers migrated to and settled in Utah (Park 2013; Reeve 2015a). In its early years, the LDS Church was racialized by US media and politicians as non-White in response to its members' practice of polygamy combined with the religion's racial inclusivity (Reeve 2016). In an attempt to (re)establish the religion's Whiteness, church leadersbeginning in 1852 with the religion's prophet at the time, Brigham Young-slowly introduced a number of policies that allowed Black believers to be baptized but barred them from receiving priesthood authority (required for holding church leadership positions) and from participating in sacred ordinances in church temples (thus withholding eternal promises and blessings from them; Reeve 2015a, 2020). While these "priesthood ban" policies were seemingly imposed based on a "one-drop" rule (applying the restrictions to members with any African ancestry), in practice they were left up to interpretation and often enforced based on skin color as much (if not more than) ancestry (Murphy 1999). ${ }^{3}$ Through these policies, colorism became a practice of the LDS Church until the bans were officially repealed a century-and-a-quarter later in 1978 (Reeve 2015a).

This structural, race-based policy of exclusion promoted anti-Black ways of thinking that not only directly affected LDS Church membership, growth, and leadership but also the religion's less-tangible but equally powerful culture and beliefs. The justifications offered by leaders in the religion to legitimize the race-based exclusion, coupled with the adoption of many culturally White Christian traditions, contributed to a culture of Whiteness and white supremacy among adherents to the LDS faith that have long outlasted the priesthood ban (LDS Church n.d.b; Reeve 2015b). Although the priesthood ban was lifted more than 40 years ago, vestiges of Whiteness and white supremacy remain deeply rooted in "Mormon culture" (Stiles 2014; Hendrix-Komoto 2016). In Utah, 55 percent of the state's residents are LDS/Mormon and, as a result, this "Mormon culture" predominates throughout the state, within and outside of specifically religious settings (Pew 2020; Stiles 2014).

In Utah, this anti-Black religious legacy combines with the White supremacist legacy of US immigration laws to create a system in which Whiteness among both migrants and non-migrants is "normal" and non-Whiteness (especially Blackness) is seen as an unnatural, undesirable aberration from the norm (Golash-Boza et al. 2019). Given Utah's unique religious, social, and cultural relationship to immigration and race, we use this case to ask: how do race, religion, and culture shape integration among immigrants? Based on our analysis of interviews with 70 racially diverse immigrants who have lived in Utah for an average of 13 years, we find that both race and LDS Church membership influence immigrants' social integration in Utah, creating a hierarchy of belonging with White LDS immigrants reporting the highest levels of integration and non-White, nonLDS immigrants reporting the lowest levels of integration. For immigrants of color who belong to the LDS Church and White immigrants who do not, their partial (non)normative status results in incomplete inclusion that fluctuates based on the different social and cultural settings they inhabit. Our analysis suggests that immigrant integration and sense of belonging are shaped by both the structures of inequality imposed and enforced by (non)governmental institutions and the cultural beliefs designed to maintain and normalize the inequalities those structures impose. Thus, efforts to increase integration and belonging among immigrants must not only work to dismantle legal and structural inequalities but also actively change the cultural narratives associated with them.

\section{Methodology}

The analysis presented below is based on interviews with 70 immigrants who have lived in the US for at least five years and in Utah for at least two years. Study participants could be from any country and have immigrated to the US at any age. Table 1 summarizes the relevant demographic information of the study participants. As with most interview- 
based research, the study population was not randomly selected and is not statistically representative of the Utah immigrant population. Despite this, research suggests that responses from interview participants can still provide important insights that are not easily captured through representative survey methods, especially among "hard-to-survey" populations such as immigrants (Edwards et al. 2014; Marrow 2011; Schmalzbauer 2014; Maldonado 2014; Dreby 2015; Silver 2018).

Table 1. Summary of interviewee demographic information.

\begin{tabular}{|c|c|c|}
\hline Demographic Category & $\mathbf{n}$ & $\%$ \\
\hline \multicolumn{3}{|l|}{ Sex } \\
\hline Male & 31 & 44 \\
\hline Female & 39 & 56 \\
\hline \multicolumn{3}{|c|}{ Geographic Region of Origin a } \\
\hline Canada & 2 & 3 \\
\hline Mexico & 12 & 17 \\
\hline Central America & 5 & 7 \\
\hline Caribbean & 3 & 4 \\
\hline South America & 24 & 34 \\
\hline Europe & 7 & 10 \\
\hline Africa & 4 & 6 \\
\hline Asia & 13 & 19 \\
\hline \multicolumn{3}{|l|}{ Years in US } \\
\hline $5-9$ & 26 & 37 \\
\hline $10-19$ & 17 & 24 \\
\hline $20+$ & 27 & 39 \\
\hline Average & 17 & \\
\hline \multicolumn{3}{|l|}{ Years in Utah } \\
\hline $2-4$ & 15 & 21 \\
\hline $5-9$ & 19 & 27 \\
\hline $10-19$ & 20 & 29 \\
\hline $20+$ & 16 & 23 \\
\hline Average & 13.1 & \\
\hline \multicolumn{3}{|l|}{ Religious Affiliation } \\
\hline LDS & 48 & 68 \\
\hline Christian & 7 & 10 \\
\hline Other & 3 & 4 \\
\hline None & 6 & 9 \\
\hline Not specified & 6 & 9 \\
\hline \multicolumn{3}{|l|}{ Importance of Religion } \\
\hline Unimportant & 6 & 9 \\
\hline Somewhat Important & 8 & 11 \\
\hline Quite Important & 9 & 13 \\
\hline Extremely Important & 46 & 65 \\
\hline \multicolumn{3}{|l|}{ Education Level $^{\circ}$} \\
\hline At Least Some College & 63 & 90 \\
\hline High School Diploma & 7 & 10 \\
\hline \multicolumn{3}{|l|}{ Marital Status } \\
\hline Never Married & 23 & 33 \\
\hline Married & 40 & 57 \\
\hline Divorced/Separated & 7 & 10 \\
\hline
\end{tabular}

Interviews were conducted by a team of student researchers, including students in a senior-level sociology of immigration course. Student interviewers identified and selected qualifying individuals for participation in the study through their personal and social networks; most interviewers conducted one to two interviews total. Interviewers conducted the interviews in person or virtually between March 2019 and November 2020. All interviews were recorded and transcribed by the interviewers. Participants received USD $\$ 20$ for participating in the study. 
The interviews analyzed here are part of a broader project examining subject-centered understandings and perceptions of integration among immigrants and refugees living in Utah (Zhou et al. 2008; Marrow 2013). Interviewees participating in the study complete a brief questionnaire and a semi-structured, open-ended interview lasting roughly one hour. The questionnaire asks for basic demographic information, as well as information regarding food and financial security, and physical, mental, and emotional health. The open-ended interview guide includes questions regarding interviewees' motivations for immigrating; their expectations, challenges, and accomplishments; and their definitions and self-evaluations of success, integration, and belonging. In order to protect vulnerable participants, interviewees are not directly asked about their legal immigration status, though many interviewees volunteer that information during the interview. Notably for this analysis, most interviewees were also not asked explicitly about how race/racism and/or religion have affected their experience in Utah, though as shown below, many study participants explicitly discussed the roles of race, racism, and religion in directly shaping their sense of belonging, inclusion, and integration.

After an initial analysis of interviews by the first and second authors suggested an interaction between racial and religious structures in shaping integration, all four study authors collectively coded and analyzed the transcripts of all seventy interviews. The study authors are all women, three women of color and one White woman; one native to Utah, the rest transplants to Utah from elsewhere in the US (one of whom is an immigrant from Mexico who came to the US as a small child). All four authors are members of the LDS Church. We recognize that, as in all research, our different identities and affiliations have likely shaped the themes we have identified in the interviews, our understandings and interpretations of those themes, and the ways we have connected those themes to broader sociological trends. That said, we believe we have been true to the data and to the interviewees' responses in our analysis, which follows below.

\section{The Role of Race and Racism in Shaping Immigrant Sense of Belonging in Utah}

There are two prominent dimensions of inclusion/exclusion for immigrants living in Utah: race (racism) and LDS Church membership. Both dimensions shape immigrants' social, cultural, and economic inclusion in Utah. With regard to the ways race and racism affect immigrants' inclusion and sense of belonging, two clear trends emerged: (1) Whiteness is perceived as both the racial norm and the "preferred" racial group in Utah; and (2) colorism, and anti-Blackness in particular, underlies most racism directed at immigrants in Utah. Given these two trends, there was a stark difference in interviewees' experiences with racism and their sense of belonging in Utah based on their skin color.

Whiteness. For White and White-passing interviewees, who described themselves as "light-skinned", having "light eyes", and/or as "White", their racial position has garnered them seemingly automatic "insider status." As Sam, from Canada, put it, as a "White immigrant [ ... ] I never felt like I didn't belong." For these White immigrants, being an immigrant-even one whose native language was not English-often becomes an asset, something "cool" that motivates people "to talk to me and be my friend" (Georgi, Belgium). This inclusion and acceptance led Lynn, from South Africa, to declare herself as "completely assimilated".

Because Whiteness is so closely associated with "native-ness" and presumed belonging in Utah, some White and White-passing immigrants have to remind people that they are not from Utah or that English is not their first language. Alexandra, from Finland, discussed struggling at times with the fact that "on the outside it looked like I was perfectly assimilated, but I really wasn' $t$ ", as she struggled to attain fluency in English. Even 24 years after immigrating to the US, she "still ha[s] to remind people that I'm an immigrant, and there's a reason why maybe socially I don't fit in [sometimes]." For White and Whitepassing interviewees, regardless of their country of origin and native language, their racial status brings automatic inclusion and assumptions of belonging, sometimes beyond 
what the immigrants themselves feel is accurate. Apparently, in many different settings, Whiteness is equivalent to belonging in Utah.

This automatic inclusion appears to be directly tied to skin color, something a number of White and White-passing immigrants acknowledged. Naomi, from Spain, did not realize how much "the fact that I am not dark skinned" affected her life until she immigrated to the US, noting how "being around people that are darker skinned" and observing the way they are treated differently from her has led her to recognize the role skin color plays in shaping experiences and opportunities in America. Alejandra, from Ecuador, has reached a similar conclusion based on her experiences and observations, noting that "because of all the stories from my peers who have experienced discrimination, I've realized that because I am fair-my skin is light-I have not experienced that same discrimination as peers from [my] country." While not all White and White-passing interviewees directly acknowledged their racial privilege as Naomi, Alejandra, and Sam did, their silence regarding experiences with race and racism — contrasted with non-White interviewees' overwhelming description of colorist racist encounters-strongly suggests that skin color underlies many racist encounters in Utah.

Non-Whiteness. While Whiteness served to fast-track inclusion for some interviewees, non-Whiteness functioned as a source of exclusion and othering for many of the immigrants we interviewed. Part of this exclusion comes from Utah's lack of racial diversity, which put many non-White interviewees in situations where their racial difference was visually obvious. Interviewees mentioned being one of the only people of color in school, at work, at church, and elsewhere. Lucy, from Mexico, described the region's stark lack of diversity as "like when you get popcorn and you put a little bit of black pepper and the little speckles that [you see] are like the diversity [here]." The overwhelming Whiteness of Utah made it almost inevitable that interviewees would "be singled out as the only Asian in class" (Li Jun, Hong Kong), "the only Brown kid in the whole school" (David, Mexico), with "all eyes on me" (Emmanuel, Haiti). Many interviewees described living as people of color in these super-majority White spaces as exhausting, especially because people are constantly reminding them of their racial divergence from the White norm.

However, more than the mere fact of non-White interviewees' racial difference from most Utahns, it was the racism, micro-aggressions, and judgment interviewees faced because of their skin color that left them feeling excluded and unwelcome. Interviewees experienced this racism from law enforcement and government officials, teachers and bosses, coworkers, roommates, peers, and strangers. Racism from these different sources introduces distinct threats for immigrants: from government actors, the threat of legal (and for some, physical) exclusion from the US; from teachers, bosses, and friends, the threat of social, economic, and cultural exclusion; and from strangers, the threat of physical and emotional violence. Increases in these racist incidents following the rise of Donald Trump multiplied their accompanying threats, further exacerbating the risks immigrants in Utah face and the sense that, as much as they "want to believe that we belong here" (Mary, Ecuador), they do not and cannot fully belong.

Interviewees' frustrations with and fears surrounding their racist encounters with government actors stemmed from the potential legal consequences they could face (including loss of legal immigration status and/or deportation) and the sense that the treatment they received from government officials was determined by their race, rather than their actions. A police officer pulled Juan, from Mexico, over after he rolled through a stop sign (as had the car in front of him), and what he thought would be a simple encounter resulting in a warning or, maybe, a ticket, ballooned into a frightening and much more serious encounter. The officer called for backup and, suddenly, "I have like four police officers around me, [ ... ] they're making sure I don't run out of the car, making sure I don't drive away. [ ... ] I'm feeling like a criminal. I feel like I've done something awful." This escalation surprised Juan because it was so different from all of the stories his White friends had told him about their encounters with police: 
Out of all my White friends that had told me about their experience with police officers-[that it was a] safe situation when they had a reasonable [explanation]-I felt like I had tried to do the same thing. I tried to be fair, and I tried to be honest. But it felt like everything that I was saying was just getting thrown away like it was invalid. [ . . . I felt like I wasn't given an opportunity to really explain myself or really be understood.

Instead, he was given USD $\$ 800$ worth of tickets and was prohibited from driving home. A number of other interviewees echoed Juan's frustration at feeling that their negative treatment by government authorities stemmed from their racial status. As she described a recent encounter with a police officer, Lucy noted that, "As an immigrant or as someone of color, you're always just kind of on edge, being like, 'What are they really doing this for? [ ... ] If I was a different color, would you be checking up on me as much as you would on anyone else?'" Enrique, from Guatemala, and his friends had similar questions after being pulled over for speeding, thinking, "They might have only done that because they saw that it was three Hispanics in the car." Diana, from Mexico, who has been accused of child abuse by her ex-husband (a White US citizen) and now must interact with agents from the Utah Division of Child and Family Services (DCFS), feels like "because I'm an immigrant, [ . . DCFS] pays more attention to him [my ex-husband]" and pushes Diana and her concerns aside, prioritizing "whatever he worries about or whatever he wants to say $[\ldots]$ and $[\mathrm{I}]$ can wait".

For immigrants, the consequences of racist interactions with government agents cannot be overstated. Losing the custody of a child with a different citizenship can create additional problems and lead to further loss of parental rights for immigrant parents, especially if they move or are forced outside of the US in the future (Capps et al. 2015; Dreby 2012). Even minor infractions can lead to the cancellation of legal status, something that José, a DACA recipient from Mexico, knew all too well when he was pulled over for speeding, wrongfully arrested for a suspended license, and forced to take a drug test while in custody because "they thought I was high or something." He recognized that he "could have fought it more", but he had to "be as compliant as possible. I didn't want to cause any infractions because even a misdemeanor would make me lose DACA, so I have to be super, super careful." After a tearful call to his mom, who was able to bail him out, and a successful challenge in court, all charges against José were dropped and his DACA status remained unaffected. But it will be a long time, if ever, before he forgets "the most terrifying hour-and-a-half of my life" when the police told him "we have to talk to immigration now [ ... and] I was sitting in a jail cell thinking, 'Oh my God, is this it? Am I going to [be sent] to Mexico?' I've never been before, it's a place I've never even known." The unpredictability of how encounters with police and other government officials will play out-especially when so many immigrants of color have experienced racial profiling-leads many immigrants of color to avoid interacting with these officials at all costs. As Enrique put it:

I think some people when they see a policeman, they hope to feel safe, they hope to feel good. But that's not really my experience. When I see a policeman, I feel somewhat scared. I try to avoid them and, yeah, just stay away from them.

The threat of legal exclusion that can be so easily inflicted by law enforcement and other government officials weighs heavily on the minds of immigrants, especially those whose skin color and/or legal status makes them more vulnerable to the suspicion and actions of government agents.

While interviewees may have felt able to avoid interacting with government officials and minimize their risk of experiencing racism and legal exclusion through those interactions, it was much harder for them to avoid racism from their teachers, peers, employers, and coworkers and the social, economic, and cultural exclusion that racism from familiar people brings with it. These racist encounters happen everywhere: at home, such as when Diana's new roommates "didn't want to let me use any of their [forks]" when she had just moved in; at school, such as when Cristina's (from Guatemala) peers "always ask me, 'Are you legal or are you illegal?"'; with friends, such as the "vibe" Mandy, from Colombia, 
felt when she, as a teenager, would go "to other people's houses and they've never seen a Hispanic in their home [ . . . and it] made me feel like they were kind of scared that I was just going to do something"; at the doctor's office, such as when Noelia's doctor chastised her for traveling to Mexico while she was pregnant and asking her, "Why do you guys always like to go back?"; at work, such as when Diana was working as a waitress and patrons at a table she was serving asked for a different server "because I was Latina and they didn't want me serving them"; and out and about in the neighborhood, such as when Marco, from Argentina, was on a jog and someone "yelled at [me] from a moving car to go back to my country." These everyday experiences with racism wear down immigrants of color, as they deal with the exhausting, never-ending task of justifying their existence to others (Williams 2012).

Many times, this racism manifested in interviewees being ignored, undervalued, or presumed to be less qualified because of their skin color. Diana described how, at work, "sometimes they just don't listen [to me] because, 'She's a woman; she's not from here; she's a Mexican' or whatever." Marco noted that, "Sometimes my opinion isn't taken as strongly as someone else's that isn't of my color." He went on to explain:

I have a few Chilean friends that look American [sic], their skin is just that color. They just look "American", and their opinion has been taken over mine, even though they don't speak English as well [as I do].

He has also experienced this racism at work and when looking for work, mentioning that "a lot of people, when I would show up for a business job, wouldn't expect me to be as smart as someone that wasn't the color of my skin." Juan has experienced similar suspicion around his abilities, with teachers and employers doubting his abilities, "never expect[ing] me to do as much as the other[s]" even though he has lived in the US since he was a child and speaks English fluently. Time and again, he has had White people in Utah expect him "to go to work in construction or painting or yard work [ ... ] and if you don't work in these things, they start making jokes about it and they start asking very inappropriate questions about it." Juan and other interviewees of color noted time and again that, despite their hard work and best efforts to belong, Whites in Utah regularly challenged their worthiness to be there-whether that was in university, at work, or just in their neighborhood.

While Alexandra, a White immigrant, had to remind others sometimes that her background as an immigrant might mean that she will not always fit in, the immigrants of color we interviewed expressed multiple experiences in which they were explicitly marked as other because they are not White and not allowed to belong, even if they had been in the US and Utah almost all of their lives. Emilia, from Chile, illustrated the essential role of race in shaping these experiences by describing the different experiences her US-born children have had, three of whom are light-skinned and are racialized as White, and one of whom is darker-skinned and is racialized as non-White. Emilia explained how her darker-skinned child "wished that she could be White because she hated how people would mention [her skin color]", which would sometimes be discussed in "complimentary" ways ("like, 'Oh, I love your skin! It's so beautiful'") and other times offered as a justification for why she received certain awards or recognition in school ("like, 'Oh yeah, you got that because you're Brown'”). Her other children never faced such treatment. Other interviewees, such as Carolina from Guatemala, noted that the "looks" and "stares" with which some Utah residents greeted them never went away, even after decades of living in the Utah: "I still get the looks", Carolina explained. "I've been here for 26 years, and I'[m still] told to 'go back'".

Interviewees also noted that their experiences with racism have increased in quantity and intensity following the political candidacy and presidency of Donald Trump. Sanja helpfully explained it as a kind of "trickle-down" racism:

A leader's view or a leader's thought process, it trickles down to the bottom part of society. [ ... ] The US is a big organization, so what it's leadership thinks, it trickles down. 
The way they are treating immigrants—“They are the reason the economy is failing"—or [... ] whatever is getting said, that gets trickled down.

The growth in reliance on "stereotypes" (Juan)—increased "suspicio[ns] of the Muslims" (Faraj, India), assumptions that "everyone that speaks Spanish is a bad person" (Desi, Chile), accusations that "Hispanics [ . . a are] robbers because we're stealing jobs" (Juan), and fear of Asians and the "China coronavirus" (Amy, Hong Kong) - "causes mental and emotional distress" (Eva, Ecuador). However, many people in Utah feel "justified" in their racism and discrimination "because the [Trump] Administration is very strong about that" (Emilia). The culmination of this racism and discrimination is that "you have to work harder to be included [ ... ] just because of your color" (Mary) and sometimes find that even that hard work is not enough to be included: "I think, in all, that's been the hardest thing-just trying to live in a place that you want to call home, but [ ... ] they don't let you call it home" (Marco).

Blackness. Blacks make-up less than two percent of Utah's population, and immigrants and refugees compose a larger percentage of Utah's Black population than in the US Black population as a whole. This means that intersecting vulnerabilities associated with race and immigrant status are higher for Black individuals in Utah than in the US generally, increasing the threat of legal, social, economic, and cultural exclusion, as well as physical and emotional violence, that accompany racism in Utah. As Caleb, from the Democratic Republic of the Congo, put it, the rising discrimination against immigrants compounds with the ongoing discrimination against Black people in America:

[The discrimination against Black people and immigrants in Utah] becomes a problem for all of us, no matter who you are, even if you are born here. When they talk about immigrants, automatically you feel that they are even talking about you, too. You become inferior. You start feeling the inferiority.

While only a handful of interviewees self-identified as Black, their responses suggest that they have experienced racism at even higher rates and across a broader range of social settings than other non-White interviewees. Black interviewees' experiences with racism in Utah overlapped significantly with those of other interviewees of color, but also suggested a more constant and extreme threat. To begin with, Blackness is treated as the antithesis of what is "normal" in Utah. As Joe, from Zambia, explained:

It's not only Black people who tell me, "What are you doing in Utah?" Even White people tell me like, "Why? What are you doing in Utah as a Black person?" [ . . ] It's just their mindset. They've always associated Utah as a predominantly White state, if that makes sense. White conservative state, let's put that qualif[ication] with the conservatism side of things as well. [ ... ] This is not only from Brown people or Black people or White people. No, I mean, from almost everybody because they've always associated Utah with Whiteness.

This strong association of Utah with Whiteness led Black interviewees to face questions and stares in most social settings in Utah. Emmanuel, who has lived in Utah since he was adopted from Haiti at age six, says that, in Utah, "I still feel like people look at me differently", something he feels is not because he is an immigrant, but "it's because I'm African-American. They automatically look at me differently because I'm a different race." For Emmanuel, an extremely social person, the permanent othering he experiences due to the color of his skin has impeded his ability to be truly seen by others and build lasting relationships. He ultimately just wishes that others "would treat me more like a person".

Other Black respondents discussed similar struggles and connected this race-based othering to exclusion they have faced in a variety of social settings, including at school and in the workplace. Caleb has seen how discrimination and "systematic racism in the United States" affect himself and his children and sees it as the "biggest [ . . ] barrier from not accomplishing what we were supposed to be-our goals." He has learned the hard way that "there's some jobs that are not meant to be for me, as a Black man, no matter what qualifications I have", and has come to expect that, for the jobs he could be hired to work, he will "be paid as a woman, not as a man. I'm expecting that because of my 
race." In addition to confronting and navigating racism in his own life, Caleb has to help his children process the racism they encounter at school ("Somebody told me at school that my skin looks like poo") and answer their unanswerable questions about anti-Blackness in America ("Dad, why White people are killing Black people?"). He has struggled to help his US-born children grapple with these issues, as he recognizes his own vulnerability to violence from the police and others:

When we're talking about police, it's horrible. You know, my skin is easy to see. We can make a mistake - the same mistake-me and you [the White interviewer] at the same time, at the same place, but when the police come, their eyes will be on me, not you.

Joe acknowledged how this conflict plays out in the lives of his two sons, wishing "for them to be treated fairly as human beings. [... ] I would like to have my child play just like another White child playing. [ ... ] There are some things that my child cannot do just because of his race." As a "Black man raising two Black boys who will eventually become Black men in America", Joe identified racism and the racial disparities in America as the greatest challenge he and his family face in the US, one that has prompted him and his wife to debate whether or not to move to another country where they and their children will face less discrimination, exclusion, and threats of violence.

All of our interviewees' comments-which were raised despite the fact that most interviewees were not explicitly asked about race during their interviews-suggest that racist beliefs, comments, and actions are rampant in Utah and deeply rooted in colorism and anti-Blackness. As a result, racism in Utah creates a spectrum of in/exclusion for immigrants, with White immigrants enjoying nearly automatic and limitless inclusion, Black immigrants suffering involuntary and inescapable exclusion, and non-Black immigrants of color falling somewhere in between those two extremes. Skin color lies at the heart of this inequality:

As soon as they notice we are a different color than the natives, there begins a great difference. And even if they are brothers, or friends, they don't trust you. What's the saying? They chew you. That is how we feel. That they chew us [like chewing gum], but don't swallow you (Raúl, Honduras).

This color-based spectrum of in/exclusion plays a significant role in shaping immigrants' sense of belonging in Utah. But it is not the sole determinant of belonging. Affiliation (or lack thereof) with the LDS Church also features prominently in immigrants descriptions of their sense of belonging in Utah, given the demographic, physical, and cultural dominance of the Church and its buildings across the state.

\section{The Role of LDS Church Affiliation in Shaping Immigrant Sense of Belonging in Utah}

Utah's lack of racial diversity is compounded by its lack of religious diversity-or, perhaps more accurately stated, the dominance of the Mormon religion, which is a minority religion everywhere in the world outside of Utah and some communities in neighboring states. The LDS Church has a unique culture-insular, supportive, "like a family" (Susan, Taiwan) - that functions as a source of inclusion and belonging in most of the world where members of the LDS Church are a small fraction of the population. However, this insularity, and often strict expectation of uniformity within the group, becomes much more problematic in Utah where a majority of the states' residents (55\%) are members of the LDS Church (Trinitapoli 2007; Stiles 2014; Pew 2020). As Lexa, from Bosnia, explained, "A lot of people, when they come to [Utah], they find it hard to integrate because the LDS community is very tight knit, and so it's really difficult for people to enter into those friend groups and meet new people." Interviewees noted that this second dimension of homogeneity creates a "bubble" (Gabrielle, France) in Utah in which people are "sometimes so closed-off" (Diane, Mexico), "fake" (Emmanuel), "narrow-minded" (Diego, Honduras), and "pretentious" (Andres, Peru), with an expectation that everyone will conform to a very strict, "black-and-white" code of behavior, dress, and thought/ideology (Alfonso, Peru). Within this culture, many feel pressure to project an image of Mormon "perfection" and others feel intimidated and excluded by that image of perfection, including Mandy, who 
said that growing up in Utah was "super-hard" because "the Mormon community [is] like, these perfect little families, and everybody goes to church, and I'm over here worried about my mom not getting caught or getting deported." Perhaps it was for this reason that, when asked at what point Mandy felt fully integrated, she said without hesitation, "the day I was baptized" into the LDS Church.

LDS Church Members. Similar to Mandy, many interviewees who were members of the LDS Church found community and belonging through their church membership. For those who were church members before moving to the US, the church provided a "familiar" setting (Phil, Argentina) and an "instant connection" (Andres) with other members at church on Sundays and in work and school lessons taught on the same Sunday in church buildings throughout the world, the same general church authorities leading and speaking to the worldwide church membership, and the same social organizations and events in place for members of all ages in each geographically organized unit. This consistency means that, while adjusting to "so many things that were different [in the US]", the Church gives its immigrant members "at least one thing that was the same to fall back upon" (Phil). For Antonio, from Italy, the consistency, familiarity, and reliability of the church has acted as a "lighthouse that [no matter where we are] allows us to say, 'Okay. We know where to go.'" Because of the way the Church is organized, "immediately after you arrive, you belong to a congregation" (Veronica, Mexico), which taps you into a geographically contained social group and connects you to a "huge support network" of people ready to serve and with financial and spiritual resources to offer (Alexandra).

It is not just about the fact that "the curriculum stays the same" but also "the similarities in the culture and the Gospel" that help you make like-minded friends and feel like you belong (Rodrigo, the Philippines). As Susan described, "Here, the Church provides another social circle for you, and emotional support. [ . . ] It's like a family." Through her church activity and affiliation since arriving to Utah, Lucy has "been able to feel at home with the people that have the same beliefs as me", something that has helped her feel like she belongs. For some immigrants who are able to attend congregations with services offered in their native language or with coethnics, Church is both a haven of spiritual inclusion and a place of ethnic, linguistic, and/or racial diversity and inclusion. (In Utah, there are many Spanish-language congregations that meet throughout the state, as well as one or a few for members speaking other non-English languages or belonging to specific racial or ethnic groups, such as "Polynesian" congregations, Native American congregations, Mandarin-speaking congregations, etc.) Noelia, who "attends a group that speaks Spanish", said that "the church helps provide that sense of community." For Emilia, her participation in a Spanish-language congregation provides more than just a sense of community; it offers her a sense of belonging. When asked where in Utah she feels most integrated, Emilia replied, "At church, of course, because it's my Hispanic community. [ ... ] When there are people similar to me, that's when I feel more integrated." For most interviewees who were (regularly attending) members of the LDS Church, their affiliation with the organization provided a strong sense of belonging and inclusion, at times in spite of the exclusion they experienced in other social settings in Utah because of their race.

However, not all LDS church members find that church membership and activity enhances their inclusion and sense of belonging. For some, participation in church meetings and interactions with church leaders and members resulted in additional experiences of exclusion, often because of explicitly racist comments and actions from other church members. Cristina has observed that the youth in her congregation "sit one side one color, and the other side of the other color [with] space in the middle" with no clear reason for why. "You can see the division there", Cristina observed. For Desi, the LDS church and its culture has been "the most challenging thing" for her in Utah: "I was very active in the church [in Chile], and then I moved here. And it's because of the culture at church. People are very judgmental." Where in Chile Desi had found community and inclusion, in Utah she felt judged and excluded. Amy, from Hong Kong, experienced similar exclusion from her supposed church friends (who were also, because of the geographic organization of church 
congregations, her neighbors) following her divorce from her husband: "Sometimes they ask me a question or something that seems like they thought I move here, I want to look for the American guys to be married, and divorce my husband and something like that." When they were not making her feel bad about her divorce, these "friends" / neighbors tried to pressure her to find a new Chinese husband since she "doesn't know American culture" and "doesn't speak English very well. [ ... ] So that's why, [for] more than 6 years, I didn't really have good conversations with the neighbors and just say hi once in a while." Others heard racism directed at them from fellow congregants (such as when one of Caleb's neighbors asked him and his wife at church, multiple times, when they would be returning to their country: "Is it not time that you go back home?"), preached from the pulpit (such as when Emmanuel heard a speaker at a regional conference declare that his observations of Latino families during his service as a missionary in South America taught him "how not to treat his wife"), and spouted directly to them by congregational leaders (such as when Caleb's bishop, the leader of his local congregation, told him, "[You are] supposed to be White, but because [you are] a descendant of Cain, who was cast out, that's why [you are] Black today"). These and other experiences have "pushed me back a lot from the church" and "make me not trust people" (Caleb), converting church for some from a haven into a hostile site of exclusion.

Non-LDS Church Members. For other immigrants in Utah who have no affiliation with the LDS Church, the insularity of Mormon culture leads to their automatic social exclusion in many settings, accompanied by pressure to accept baptism and official church membership as the only way to find true inclusion. The prevalence and power of Mormonism and Mormon culture proves particularly shocking to immigrants who have lived elsewhere in the US before moving to Utah. As Padma explained, "The most challenging thing in Utah could be the religion, which I wasn't familiar with at all before moving here. I never heard of the church, and it is very big here." After adapting to life in Michigan, "where there were lots of diverse people", Padma experienced "culture shock" as she confronted a completely new and unfamiliar Utah-specific culture while also navigating its lack of racial diversity and its population's limited familiarity with her own country and culture ("People had never heard about India. [ . . . ] They didn't know about Indian people"). Similar to Padma, An, from China, identified "the most challenging thing about living in Utah" as "cultural things: that I'm not a Mormon", an added layer of exclusion she had not experienced or anticipated prior to moving to Utah. She continued:

I came in from one culture [China] to another culture [North Carolina], and I finally feel like I'm part of it. Then I come to another culture [Utah] and I feel like I'm getting schooled again. And I don't want to be included. It's not-it's not because I hate the [LDS] church, I just don't like the culture.

Part of the discomfort with Mormon culture comes from the constant pressure to fully, officially embrace it. For An, this made it "hard to find the right friends because everybody I talk to [tries] to convert me." The LDS Church strongly emphasizes proselyting with friends and neighbors and given that the majority of Utah residents already belong to the church, those who do not often face relentless pressure from everyone around them to join. For those who choose not to affiliate with the church, they toggle back and forth between feeling "a lot of pressure or left out" (Alexa, Dominican Republic). Alexa was explicitly excluded by others on multiple occasions after they learned she was not a member of the LDS Church: "their attitude would change or they wouldn't want to talk anymore or kept their distance because I wasn't [Mormon]. [ ... ] I felt like people didn't accept me just because I wasn't in the same church as they were." While she was finally able to find "people who were open-minded like myself", the pain of exclusion remained. Abdul identified this tendency toward judgment and exclusion as a product of the insularity of Utah Mormon culture:

Everybody has a judgmental view of you because either they lack the understanding or because they have never stepped outside the regular domains. And they couldn't really understand the other values which are important to other people. 
This lack of understanding across religious and racial lines makes inclusion and belonging an elusive goal for many non-White and non-LDS immigrants in Utah. As David observed, "Some places it's harder to be an immigrant than others, and Utah is definitely one of them".

\section{Discussion}

The study participants' experiences suggest that the complex, multi-faceted history of institutional racial inequality in Utah and the lasting cultural narratives that were developed and broadly disseminated to justify those inequalities create a kind of hierarchy of belonging for immigrants in which skin color and the acceptance or rejection of Mormon culture combine to shape their sense of belonging in Utah. In this hierarchy of belonging, interviewees who are White and White-passing LDS Church members enjoyed full inclusion while those who are both non-White and non-LDS Church members felt they were treated as "double outsiders." For immigrants of color who belong to the LDS Church and White immigrants who do not, their partial (non)normative status results in incomplete inclusion that fluctuates along the inclusion-exclusion spectrum based on the different social and cultural settings they inhabit. These findings confirm and expand on arguments about how the intersections of structural and cultural systems of oppression shape migrants' experiences and integration by examining these forces in motion within a specific immigration context in which both governmental and non-governmental policies and cultures work in tandem to create an intersectional structure of inequality (Golash-Boza et al. 2019).

Structural racism and religious exclusivity create unequal opportunities and inclusion for migrants in Utah across multiple measures. Interviewees describe facing threats of exclusion across legal, physical, social, economic, and cultural dimensions in Utah based on both their skin color and their religious affiliation, all of which directly shape their sense of belonging. The anti-Black former policies of the LDS Church and White supremacist former US immigration laws-and the doctrinal and cultural explanations offered as justifications for these policies, which many still believe today-have likely contributed to immigrant exclusion in Utah within church social settings and in broader Utah society. Even though the LDS Church and US government have long abandoned those exclusionary policies, the cultural vestiges of the policies and their purported justifications appear to be much harder to disavow, contributing to the ongoing discrimination against and exclusion of non-White immigrants in Utah. This lingering cultural effect of structural racism's past is likely not unique to Utah at all, but visible in different ways in communities across the US dealing with the cultural and psychological fallout of institutional racism, past and present (Gabriel and Tolnay 2017).

Our study also demonstrates the power of non-governmental institutions such as religious organizations to both foster inclusivity and stifle it. Interviewees' experiences suggest that immigrants' LDS Church membership and participation in church life in Utah (and elsewhere in the US and abroad) generally provides them with a strong sense of community, support, and belonging. In the face of racism and other forms of exclusion, religious and other institutional affiliations can provide immigrants with social, economic, and spiritual support that directly combat the inequality, uncertainty, and exclusion immigrants face in other realms of their daily lives (Kurien 1998; Menjivar 2006). However, these same institutions can also serve as sources of exclusion for non-adherents, especially when the institutions have a broad presence within a community. Even successful efforts at creating spaces of inclusion, such as the LDS Church's Spanish-speaking congregations, may re-entrench broader forces of exclusion by isolating non-Whites from their neighbors and fellow believers.

The findings presented here suggest that immigrant inclusion requires policies and cultures that promote inclusion (Bloemraad 2006). Abandoning and disavowing former racist or otherwise exclusionary policies is not enough. Both non-governmental and governmental institutions should work to develop policies of inclusivity, especially racial inclusivity, but they cannot stop there. They should also regularly, consistently, and 
visibly promote a culture of inclusion and explicitly denounce prior policies, beliefs, and practices that have explicitly or implicitly promoted racial and other forms of exclusion. Both cultural and policy-based efforts to promote inclusion are necessary to change the "collective memory" from one of othering to one of belonging (Gabriel and Tolnay 2017). While this effort to effect cultural change requires much more energy, exertion, and stamina than policy change alone, it is undoubtedly a righteous cause worth pursuing.

Author Contributions: Conceptualization, G.M. and J.L.L.; methodology, J.L.L.; coding and validation, G.M., C.V. and N.T.A.; formal analysis, J.L.L., G.M., C.V. and N.T.A.; investigation, J.L.L., G.M. and C.V.; resources, J.L.L.; data curation, J.L.L. and G.M.; writing—original draft preparation, J.L.L.; writing-review and editing, J.L.L., G.M., C.V. and N.T.A.; supervision, J.L.L.; project administration, J.L.L.; funding acquisition, J.L.L. All authors have read and agreed to the published version of the manuscript.

Funding: This research received no external funding.

Institutional Review Board Statement: The study was conducted according to the guidelines of the Declaration of Helsinki and approved by the Institutional Review Board of Brigham Young University (protocol code X19015/X2019-430, approved 27 February 2019).

Informed Consent Statement: Informed consent was orally obtained from all subjects involved in the study (written consent was not obtained to protect participants' identities).

Data Availability Statement: Due to privacy concerns, the data are not publicly available but may be made available upon request to the first author.

Acknowledgments: The authors are grateful to all of the interviewees for their participation in this study. The authors are also thankful for the special issue editors and the anonymous reviewers for comments on previous versions of this manuscript.

Conflicts of Interest: The authors declare no conflict of interest.

\section{Notes}

Knowing which groups/immigrants qualified as "White" was difficult, as inclusions and exclusions from this category shifted quite regularly during this time; often, concerned parties turned to the courts to resolve the question (the legal determinations of Whiteness by the courts shifted over time, too; López 1997; Molina 2014).

The Utah Compact urges state lawmakers to adopt five principles when considering and developing state-level immigration policy, including both an emphasis on federal solutions and the need for law enforcement and a recognition of the key role of immigrants in supporting Utah families and the state's economy. The full statement and its signatories can be found here: https:/ / theutahcompact.com/compact-\%26-signatories (accessed on 14 June 2021).

3 A number of White-passing members, some with widely known African ancestry, received priesthood and temple ordinances throughout the ban (Reeve 2020).

\section{References}

American Integration Council (AIC). 2020. Fact Sheet: Immigrants in Utah. Available online: https:/ / www.americanimmigrationcouncil. org/research/immigrants-in-utah (accessed on 7 January 2021).

Armenta, Amada. 2017. Racializing Crimmmigration: Structural Racism, Colorblindness, and the Institutional Production of Immigrant Criminality. Sociology of Race and Ethnicity 3: 82-95. [CrossRef]

Bacchus, Nazreen S. 2020. Belonging and Boundaries in Little Guyana: Conflict, Culture, and Identity in Richmond Hill, New York. Ethnicities 20: 896-914. [CrossRef]

Bloemraad, Irene. 2006. Becoming a Citizen in the United States and Canada: Structured Mobilization and Immigrant Political Incorporation. Social Forces 85: 667-95. [CrossRef]

Bonilla-Silva, Eduardo. 2001. White Supremacy and Racism in the Post-Civil Rights Era. Boulder: Lynne Reinner Publishers, Inc.

Cadge, Wendy, and Elaine Howard Ecklund. 2007. Immigration and Religion. Annual Review of Sociology 33: 359-79. [CrossRef]

Capps, Randy, Heather Koball, Andrea Camptetella, Krista Perreira, Sarah Hooker, and Juan Manuel Pedroza. 2015. Research Report: Implications of Immigration Enforcement Activities for the Well-Being of Children in Immigrant Families. Washington, DC: Urban Institute and Migration Policy Institute.

Chin, Gabriel J. 1996. The Civil Rights Revolution Comes to Immigration Law: A New Look at the Immigration and Nationality Act of 1965. North Carolina Law Review 75: 273-345. 
Coppins, McKay. 2020. The Most American Religion. The Atlantic. December 16. Available online: https://www.theatlantic.com/ magazine/archive/2021/01/the-most-american-religion/617263/ (accessed on 6 January 2021).

Davidson, Lee. 2021. Latter-Day Saints Are Overrepresented in Utah's Legislature, Holding 9 of Every 10 Seats. The Salt Lake Tribune. January 14. Available online: https://sltrib.com/news/politics/2021/01/14/latter-day-saints-are/ (accessed on 9 June 2021).

Dreby, Joanna. 2012. The Burden of Deportation on Children in Mexican Immigrant Families. Journal of Marriage and Family 74: 829-45. [CrossRef]

Dreby, Joanna. 2015. Everyday Illegal: When Policies Undermine Immigrant Families. Berkeley: University of California Press.

Ebaugh, Helen Rose, and Mary Curry. 2000. Fictive Kin as Social Capital in New Immigrant Communities. Sociological Perspectives 43: 189-209. [CrossRef]

Edwards, Brad, Kirk M. Wolter, Nancy Bates, Roger Tourangeau, and Timothy P. Johnson, eds. 2014. Hard-to-Survey Populations. Cambridge: Cambridge University Press.

FitzGerald, David Scott, and David Cook-Martin. 2014. Culling the Masses: The Democratic Origins of Racist Immigration Policy in the Americas. Cambridge: Harvard University Press.

Flores-González, Nilda. 2017. Citizens but not Americans: Race and Belonging among Latino Millenials. New York: New York University Press.

Foner, Nancy, and Richard Alba. 2008. Immigrant Religion in the US and Western Europe: Bridge or Barrier to Inclusion? International Migration Review 42: 360-92. [CrossRef]

Gabriel, Ryan, and Stewart Tolnay. 2017. The Legacy of Lynching? An Empirical Replication and Conceptual Extension. Sociological Spectrum 37: 77-96. [CrossRef]

Golash-Boza, Tanya. 2015. Deported: Immigrant Policing, Disposable Labor, and Global Capitalism. New York: New York University Press.

Golash-Boza, Tanya, and Pierrette Hondagneu-Sotelo. 2013. Latino Immigrant Men and the Deportation Crisis: A Gendered Racial Removal Program. Latino Studies 11: 271-92. [CrossRef]

Golash-Boza, Tanya, Maria D. Dueñas, and Chia Xiong. 2019. White Supremacy, Patriarchy, and Global Capitalism in Migration Studies. American Behavioral Scientist 63: 1741-59. [CrossRef]

Kem C. Gardner Policy Institute (GPI). 2017a. Fact Sheet: Refugees in Utah. In Informed Decisions. Salt Lake City: University of Utah.

Kem C. Gardner Policy Institute (GPI). 2017b. Fact Sheet: Race and Ethnicity in Utah, 2016. In Informed Decisions. Salt Lake City: University of Utah.

Hartley, William G. Missouri. 1838. Extermination Order and the Mormon's Forced Removal to Illinois. Mormon Historical Studies 2: 5-27.

Hendrix-Komoto, Amanda. 2016. 'Do They See Me?' Race and Mormon History. Reviews in American History 44: 450-56. [CrossRef]

Hodes, Martha. 2003. The Mercurial Nature and Abiding Power of Race: A Transnational Family Story. The American Historical Review 108: 84-118. [CrossRef]

Jiménez, Tomás. 2010. Replenished Ethnicity: Mexican Americans, Immigration, and Identity. Berkeley: University of California Press.

Jiménez, Tomás, and Adam L. Horowitz. 2013. When White is Just Alright: How Immigrants Redefine Achievement and Reconfigure the Ethnoracial Hierarchy. American Sociological Review 78: 849-71. [CrossRef]

Kim, Claire Jean. 1999. The Racial Triangulation of Asian Americans. Politics E Society 27: 105-38.

Kurien, Prema. 1998. Becoming American by Becoming Hindu: Indian Americans Take Their Place at the Multicultural Table. In Gatherings in Diaspora: Religious Communities and the New Immigration. Edited by Stephen Warner and Judith G. Wittner. Philadelphia: Temple University Press.

LDS Church. 2011. The Church of Jesus Christ of Latter-day Saints (LDS Church). Immigration: Church Issues New Statement; Salt Lake City: Church Newsroom, June 10. Available online: https://newsroom.churchofjesuschrist.org/article/immigration-church-issuesnew-statement (accessed on 3 June 2021).

LDS Church. 2018. The Church of Jesus Christ of Latter-day Saints (LDS Church). Church Statement on Separation of Families at the US-Mexico Border. Salt Lake City: Church Newsroom, June 18, Available online: https:/ / newsroom.churchofjesuschrist.org/article/churchstatement-separation-of-families-at-us-mexico-border (accessed on 3 June 2021).

LDS Church. n.d. a. The Church of Jesus Christ of Latter-day Saints (LDS Church). Topic: Immigration. Salt Lake City: Church Newsroom, Available online: https:/ / newsroom.churchofjesuschrist.org/official-statement/immigration (accessed on 3 June 2021).

LDS Church. n.d.b. The Church of Jesus Christ of Latter-day Saints (LDS Church). No date. "Race and the Priesthood". Gospel Topics Essays. Available online: https://www.churchofjesuschrist.org/study/manual/gospel-topics-essays/race-and-the-priesthood? lang=eng (accessed on 5 January 2021).

Lee, Catherine. 2013. Fictive Kinship: Family Reunification and the Meaning of Race and Nation in American Immigration. New York: Russell Sage Foundation.

Liasson, Mara. 2011. Utah's New Immigration Law: A Model For America? National Public Radio. March 18. Available online: https:/ / www.npr.org/2011/03/18/134626178/utahs-new-immigration-law-a-model-for-america (accessed on 7 June 2021).

Livingston, Lindsay. 2018. Brandishing Guns: Performing Race and Belonging in the American West. Journal of Visual Culture 17: 343-55. [CrossRef]

López, Ian Haney. 1997. White by Law: The Legal Construction of Race. New York: New York University Press.

Maldonado, Marta María. 2006. Racial Triangulation of Latino/a Workers by Agricultural Employers. Human Organization 65: 353-61. [CrossRef] 
Maldonado, Marta María. 2014. Latino Incorporation and Racialized Border Politics in the Heartland: Interior Enforcement and Policeability in an English-Only State. American Behavioral Scientist 58: 1927-45. [CrossRef]

Marrow, Helen. 2011. New Destination Dreaming: Immigration, Race, and Legal Status in the Rural American South. Stanford: Stanford University Press.

Marrow, Helen. 2013. Assimilation in New Destinations. Daedalus 142: 107-22. [CrossRef]

Martinez, Brandon C., and Kevin D. Dougherty. 2013. Race, Belonging, and Participation in Religious Congregations. Journal for the Scientific Study of Religion 52: 713-32. [CrossRef]

Menjívar, Cecilia. 2006. Liminal Legality: Salvadoran and Guatemalan Immigrants' Lives in the United States. American Journal of Sociology 111: 999-1037. [CrossRef]

Molina, Natalia. 2014. How Race is Made in America: Immigration, Citizenship, and the Historical Power of Racial Scripts. Berkeley: University of California Press.

Mulder, William. 1954a. Through Immigrant Eyes: Utah History at the Grass Roots. Utah Historical Quarterly 22: 41-55.

Mulder, William. 1954b. Mormonism's 'Gathering': An American Doctrine with a Difference. Church History 23: 248-64. [CrossRef]

Murphy, Thomas W. 1999. From Racist Stereotype to Ethnic Identity: Instrumental Uses of Mormon Racial Doctrine. Ethnohistory 46: 451-80.

Park, Benjamin E. 2013. Early Mormon Patriarchy and the Paradoxes of Democratic Religiosity in Jacksonian America. American Nineteenth Century History 14: 183-208. [CrossRef]

Park, Haeyoun. 2015. Which States Make Life Easier or Harder for Illegal Immigrants. The New York Times. March 29. Available online: https:/ / www.nytimes.com/interactive/2015/03/30/us/laws-affecting-unauthorized-immigrants.html (accessed on 7 June 2021).

Petrezelka, Peggy, and Paul Jacobs. 2016. Why Utah? The 'Reddest of Red States' and Inclusive Immigration Reform. The Social Science Journal 53: 156-66. [CrossRef]

Pew Research Center (Pew). 2020. Religious Landscape Study: Adults in Utah. Available online: https://www.pewforum.org/ religious-landscape-study/state/utah/ (accessed on 7 January 2021).

Reeve, W. Paul. 2015a. Religion of a Different Color: Race and the Mormon Struggle for Whiteness. Oxford: Oxford University Press.

Reeve, W. Paul. 2015b. The Mormon Church in Utah. In The Oxford Handbook of Mormonism. Edited by Terry L. Givens and Philip L. Barlow. Oxford: Oxford University Press, pp. 38-54.

Reeve, W. Paul. 2016. Race, the Priesthood, and Temples. In A Reason for Faith: Navigating LDS Doctrine and Church History. Edited by Laura Harris Hales. Utah: Religious Studies Center and Deseret Book, pp. 159-78.

Reeve, W. Paul. 2020. Making Sense of the Church's History on Race. Faith Matters. June 30. Available online: https: / / faithmatters. org/making-sense-of-the-churchs-history-on-race/ (accessed on 4 January 2021).

Reiss, Jana. 2019. The Next Mormons: How Millennials Are Changing the LDS Church. Oxford: Oxford University Press.

Ribas, Vanesa. 2016. On the Line: Slaughterhouse Lives and the Making of the New South. Berkeley: University of California Press.

Romanello, Brittany. 2020. Multiculturalism as Resistance: Latina Migrants Navigate US Mormon Spaces. Dialogue: A Journal of Mormon Thought 53: 5-31.

Romboy, Dennis. 2008. Debate Resumes Over Illegal Immigrants' Status in LDS Church. Deseret News. February 15. Available online: https:/ / www.deseret.com/2008/2/15/20070872/debate-resumes-over-illegal-immigrants-status-in-lds-church (accessed on 8 June 2021).

Schmalzbauer, Leah. 2014. The Last Best Place? Gender, Family, and Migration in the New West. Stanford: Stanford University Press.

Silver, Alexis M. 2015. Clubs of Culture and Capital: Immigrant and Second-Generation Incorporation in a New Destination School. Ethnic and Racial Studies 38: 824-40. [CrossRef]

Silver, Alexis M. 2018. Shifting Boundaries: Immigrant Youth Negotiating Naitonal, State, and Small-Town Politics. Stanford: Stanford University Press.

Stevenson, Jason, and Marina Lowe. 2019. Utah Passed a Law to Protect Noncitizens from Automatic Deportation. American Civil Liberties Union, April 9. Available online: https://www.aclu.org/blog/immigrants-rights/deportation-and-due-process/utahpassed-law-protect-noncitizens-automatic (accessed on 7 June 2021).

Stiles, Erin E. 2014. Imagining a Mormon Culture: Gender, Religion, and Marriage in Cache Valley, Utah. Proceedings of the Southwestern Anthropological Association 2014: 10-14.

Stinner, William F., and Michael B. Toney. 1980. Migrant-Native Differences in Social Background and Community Satisfaction in Nonmetropolitan Utah Communities. In New Directions in Urban-Rural Migration: The Population Turnaround in Rural America. Edited by David L. Brown and John M. Wardwell. New York: Academic Press.

Trinitapoli, Jenny. 2007. 'I Know This Isn't PC, But ... ': Religious Exclusivism among US Adolescents. The Sociological Quarterly 48: 451-83. [CrossRef]

Vock, Daniel C. 2011. Utah on Immigration: We Aren't Arizona. Washington: The Pew Charitable Trusts, March 25, Available online: https:/ / www.pewtrusts.org/en/research-and-analysis/blogs/stateline/2011/03/25/utah-on-immigration-we-arentarizona (accessed on 8 June 2021).

Waters, Mary C. 1999. Black Identities: West Indian Immigrant Dreams and American Realities. New York: Russell Sage Foundation.

Williams, David R. 2012. Miles to Go before We Sleep: Racial Inequities in Health. Journal of Health and Social Behavior 53: $279-95$. [CrossRef] [PubMed] 
Wright, Bradley R. E., Michael Wallace, Annie Scola Wisnesky, Christopher M. Donnelly, Stacy Missari, and Chirstine Zozula. 2015. Religion, Race, and Discrimination: A Field Experiment of How American Churches Welcome Newcomers. Journal for the Scientific Study of Religion 54: 185-204. [CrossRef]

Zhou, Min. 1997. Segmented Assimilation: Issues, Controversies, and Recent Research on the New Second Generation. International Migration Review 31: 975-1008. [CrossRef]

Zhou, Min, Jennifer Lee, Jody Agius Vallejo, Rosaura Tafoya-Estrada, and Yang Sao Xiong. 2008. Success Attained, Deterred, and Denied: Divergent Pathways to Social Mobility in Los Angeles' New Second Generation. Annals of the American Academy of Political and Social Science 620: 37-61. [CrossRef] 